\title{
The Role of Principal Leadership in Improving Teacher Performance in Gugus Dua Muara Telang District
}

\author{
Zainal Muttaqin $^{1 *)}$, Happy Fitria ${ }^{2}$, Yessi Fitriani ${ }^{2}$ \\ ${ }^{I}$ SD Negeri 7 Gugus Dua, Muara Telang \\ ${ }^{2}$ Universitas PGRI, Palembang, Indonesia \\ "Corresponding author. Email: zainalmuttaqin.spd@gmail.com
}

\begin{abstract}
The purpose of this research is to identify and characterize the role of principal leadership in improving teacher performance in the Gugus Dua Muara Telang District. This study employs qualitative methods. Data was gathered through interviews, observations, and documentation. Data reduction, data presentation, and conclusion drawing were used to interpret the data. From the results of this study concluded that the role of school leadership in improving teacher performance are as follows a) as an executor; b) as a planner; c) as an expert; d) as a supervisor of the relationship between group members; e) representing the group, f) to act as a reward/praise and punishment giver; g) to act as a referee and mediator; h) to hold the responsibility of the members of the group; i) to be a creator/aspirant, and j) act as father. Supporting and inhibiting factors in the form of all school principal programs that can determine are internal and external factors, facilities and infrastructure, methods and programs, the environment and so on can support all activities to improve teacher performance, can also hinder all planned activities, thus there needs to be awareness of all parties by carrying out their duties properly.
\end{abstract}

Keywords: Leadership, Principal, Teacher Performance

\section{INTRODUCTION}

Process of human resources should cover all areas of life that should be reflected in the person of the leaders, including educational leaders such as principals. Improving the quality of human resources, particularly the principal as an education leader in schools, is a requirement for improving educational quality. In the context of regional autonomy and education decentralization, the principal is one of the educational components that plays the most important role in improving educational quality [1]. This is due to the link between the principal's leadership achievement and teacher performance. The success of a school is a school that has a leader who succeeded (effective leaders). Dimyati [2] states, the principal's leadership is one dimension of competence is crucial to the performance or success of an organization. The achievement of quality and educational goals is very much dependent on the skills and wisdom of the principal as an educational leader. Wahjosumidjo [3] states, the principal of their school is described as a person who has high expectations of the staff and the students, school leaders are those who are highly knowledgeable about the task-the task. This statement demonstrates how important the principal's leadership qualities are in achieving a school's achievement.

The principal is a professional official in charge of overseeing all organizational resources and working with teachers to educate students in order to achieve educational goals. With this school principal's professionalism, professional development of educational staff is simple because, in accordance with their function, the principal knows the needs of the school he leads, so that teacher competence is not limited to the competencies he previously possessed, but increases and develops well so that the professionalism of teacher performance will be realized [4].

The principal's behavior lies in leadership. Principal leadership according to Haryono [5] is essentially the principal's efforts to influence, encourage, guide, direct and mobilize teachers, students, parents of students and other parties who are interested in contributing to the achievement of the stated school goals. In carrying out his leadership, he is required to achieve success in various things including success in managing schools, success in learning activities, managing workforce, managing facilities and infrastructure, managing finances, overseeing the school climate and managing school-community relations. 
According to Mulyasa [4], principals of professional schools in the new paradigm of education management will have a positive impact and will result in fundamental changes in school reform. ". These impacts include, among others, teacher performance, strong school leadership, effective management of education personnel, quality culture, compact, intelligent and dynamic teamwork, independence, participation of school and community members, transparency of management, willingness to change (psychological and physical), continuous evaluation and improvement, responsive and anticipatory to needs, accountability and sustainability.

The principal must have a vision and mission, as well as an education management approach that is systematic and quality oriented. This strategy is a systematic and coordinated effort to continuously improve service quality so that the focus is directed to customers, in this case students, parents of students, users of graduates, teachers, employees, government, and society [1].

One of the duties of the principal is as a leader. The principal as a leader in the delivery of education has a central and strategic position, especially in making national education goals a top priority that must be reached optimally. This can be understood because the smooth implementation of educational tasks is very dependent on the ability of the principal in carrying out his function as a leader in the school [6]. A leadership model theory that has quite a lot of followers among management developers today is situational leadership theory. This theory is a theory that focuses on the readiness of followers or subordinates. According to this theory, the success and effectiveness of leadership depends on the level of readiness or maturity of the followers. This subordinate readiness pressure is what differentiates it from other leadership theories [7].

The pressure on followers refers to the leadership effectiveness dimension of a leader that reflects his subordinates rejecting or accepting his leadership. No matter what a leader does, effectiveness depends on his subordinates. To realize a professional teacher, the principal must direct a teacher towards competence [8].

Professional teachers are those who have competency values that are in accordance with the rules and regulations pertaining to teacher certification, namely: (1) being able to master the substance of subjects systematically, particularly subject matter specifically taught; (2) understanding and applying developmental psychology so that a teacher may choose subject matter based on the level of difficulty in accordance with the development period of the students being taught, and (3) having the ability to teach others [7].

Purwanto [9] states that as an education administrator, he is responsible for the smooth implementation of education and instruction in his school in relation to the principal's leadership.
Therefore, to be able to carry out their duties properly, the principal should understand, master and be able to carry out activities related to his function as educational administration. The principal, as a manager, must be able to use all school resources to realize the vision and mission and accomplish predetermined goals. Furthermore, the principal must be able to deal with a variety of problems at school, think analytically and conceptually, and always strive to become an intermediate teacher in dealing with a variety of problems faced by the education staff who report to him, as well as strive to make choices that are acceptable to all [4].

As manager, the chief was expected to plan, organize, supervise, and supervise. For this reason, the head of the Cluster Dua Muara Telang District school is required to always make plans and work programs, considering that this educational institution is no longer classified as young. So, the role of the manager in this case is the principal, who is highly required to always be able to develop the school. Good, from the preparation of the professionalism of education personnel, the provision of facilities and infrastructure to the satisfaction of school services for school customers.

The choice of research location at SD Negeri 7 Muara Telang District was because this school had B accreditation and implemented the K 13 curriculum which supports the learning process of teachers in the classroom, as well as the availability of facilities and infrastructure that support the learning process. In addition, principals who already have an undergraduate education background and are currently pursuing a master's degree make it easier for researchers to collect research data based on the title being studied.

The results of observations on the leadership of the Headmaster of Cluster Dua, Muara Telang District during the last four semesters, show that the principal is quite good at controlling the performance of teachers, especially discipline and enthusiasm in carrying out teaching tasks. Even though school facilities are still classified as lacking in supporting the learning process and school administration. Some classrooms are inadequate and require improvement so that they are suitable for use as student learning facilities. However, with the condition of the facilities that still need to be improved, the principal is still enthusiastic about advancing the school, especially in terms of teacher performance.

The current leadership of the principal has made teachers disciplined in carrying out their duties. This can be seen from the high percentage of teacher attendance in carrying out teaching assignments, namely the average attendance of $95 \%$. According to researchers' observations, this is due to a good example from the principal. The attitudes and responsibilities of school principals in carrying out their duties have been able to be a motivator for teachers to always improve their performance. This makes the teaching and learning 
process in Cluster Dua Muara Telang District well implemented.

The participation of the principal in leading will have an impact on the increased performance of teachers and can improve student achievement. This is important to be explored further, considering that the existence of the principal in leading an educational institution gives its own color as someone who has the authority to make important decisions and policies for the continuity of education in schools.

The role according to terminology is a set of behaviors that are expected to be owned by those in society. In English, a role is called a " role " whose definition is " person task or duty in undertaking." It means "the duty or obligation of someone in a business or work" [10].

Role is defined as a set of behaviors that are expected to be owned by people in society. While roles are actions taken by a person in an event [11].

Leadership is included in the category of applied science from because the principles, meanings, and theories are expected to be helpful in efforts to improve people's lives [12]. There are numerous concepts of leadership proposed by experts based on their respective points of view, the definitions show some similarities.

The definition of leadership according to Tead in Kartono [12] leadership is the activity of persuading others to cooperate in order to achieve common goals. Leadership, according to Kartono [12], is an activity that influences people so that they enjoy attempting to achieve group goals. According to Howard Hoyt in Kartono [12], leadership is the ability to influence human behavior and guide others. Young's definition of leadership [12]. is more focused and detailed than the previous definition. According to him, leadership is a type of dominance based on personal abilities, which is able to inspire or ask other individuals to do something based on group acceptance/acceptance, and has special skills that are suitable for special circumstances. This type of leadership is informal and is often related to the needs of the group at a specific time and in a specific location in order to accomplish certain goals.

The term "Principal" is derived from two words: "Head" and "School." The term "head" may refer to the chairman or leader of a company or organization. A medium school is a place where students and teachers can learn and teach. In general, the principal is the leader of a school or institution where there is a place to receive and give. "The principal is a functional teacher who is assigned the task of leading a school where the teaching and learning process is held, or a place where there is interaction between the teacher who gives lessons and the students who receive lessons," according to [8].

Etymologically, the term performance is derived from the words job performance or actual performance, which refer to someone's actual work performance or accomplishment. Performance is an activity carried out to carry out, complete tasks and responsibilities in accordance with the expectations and goals that have been set

\section{METHODS}

From a methodological perspective, this research is a type of qualitative research. What is meant by qualitative research is a series of activities or the process of capturing information from the normal conditions in the life of an object, connected with a problem, both from a theoretical and practical point of view

The qualitative approach in this research is descriptive. Descriptive research is research on current phenomena. The process carried out is collecting and compiling data, and analyzing and interpreting the data. In essence, qualitative descriptive research is a method of assessing the status of a group of humans or an object in order to make a systematic determination, factual and accurate descriptive, image or painting of the facts or phenomena being investigated

This approach views that reality is a dimension that is plural, intact and also changing. So, research develops during the process which makes it possible to change the concept according to the existing situation and conditions. Then this research will produce a description of the observed symptoms which do not have to be numbers.

\section{RESULTS AND DISCUSSION}

Principal leadership means empowering and utilizing existing resources that can be held efficiently and effectively to achieve the school's vision and mission. The principal is in charge of the school's administration and operations.

The principal is at the forefront of carrying out his leadership and his success can be measured. The final product of principal leadership is school performance that changes both for teachers and students. The change of teachers and students from not knowing to knowing, from inexperienced to experienced, from being unable to become able, from not achieving to being high achievers. Meanwhile, the principal's leadership target is to raise educational standards. As a result, the principal's leadership plays a significant role in shaping the quality of the individuals he leads to become the nation's next dependable generation.

Education is a process of educating the nation is used as a tool in building a complete Indonesian man. Therefore, every component related to the education process must work in synergy with one another. The components of education include the principal, teachers, and other education personnel who are able to support the activities of a school. 
In order to achieve national education goals, the main key for optimal planning and education development programs in schools is in the hands of educators and education personnel in schools. As the opinion we often hear, both directly and indirectly, is related to teacher performance, from competence to the roles and responsibilities they hold Teacher performance is an inseparable component of a system that includes input, processing, and output in order to accomplish an educational institution's goals. The context of education is different from other organizations because of its intangible nature, education expects results / products not merely quantitative outputs, but outcomes, namely competent graduates, beneficial to their environment according to the process carried out If viewed comprehensively and in depth, the teaching profession is very noble profession. Professional teachers, according to Soedijarto, are teachers with professional abilities, such as the willingness that: (1) prepare education - learning programs; (2) carry out and guide curriculum and instruction; (3) assess the progress of teaching and learning activities; and (4) interpret and use the outcomes of the project of learning progress as well as other data to improve planning for the implementation of teaching. Therefore, efforts to improve teacher performance in terms of professionalism as educators are absolutely necessary.

Responding to the importance of teacher performance, the government Law No. 14 of 2005 on Teachers and Lecturers was enacted. The law, among others, regulates matters relating to teacher professionalism. The presence of the Teacher and Lecturer Law certainly has strong reasons, because the existence of highly qualified and dedicated teachers is an important step to improve human resources. Moreover, teachers are a key element in educational organizations.

The implementation of this law in the field depends very much on the leadership of educational units such as the school principal. Therefore, the school's achievement in meeting educational objectives as outlined in the vision and mission of the school cannot be separated from a leader, in this case the principal. The principal in leading the school he leads must apply the appropriate leadership style or pattern to achieve the intended goals. A principal's role in the growth of the school he leads is critical. Leadership in question is the ability to influence others in order to achieve predetermined goals.

Meanwhile, an effective leader must be able to motivate employees, identify direction, manage change effectively, and act as a catalyst capable of coloring employees' attitudes and behavior. So that here can be seen leadership behavior in influencing the behavior of other people as shown. For this purpose, the principal as a leader in his organization must be able to mobilize school resources, especially teachers, in terms of planning, implementing and evaluating school programs, developing curriculum and learning, managing facilities and infrastructure, managing student administration and services, relations between the school and the community around and of course in the creation of a conducive school climate.

The principal's leadership has an impact on teacher performance. This means that the better the principal's leadership, the better the teacher's performance. Conversely, the lower the principal's leadership ability, the lower the teacher's achievement. Leaders usually have extraordinary verbal abilities, so they can communicate what they want to their followers. There is an extraordinary urge within him to fulfill his desires. So that the desire arises to lead people so that all their desires can be fulfilled

A leader must understand the importance of cooperation. With this ability of cooperation, a principal will also achieve success in a leadership role and the achievement of this success because the principal has succeeded in moving their followers to work together, in this case, the teachers and education staff in the school. Each leader has a style in their respective leadership in an effort to influence their subordinates.

The leadership style that is practiced in addition to depending on the character or nature of the actors, the leader itself can also be influenced by the characteristics of subordinates and the work environment. For that we need efforts to boost teacher performance. The principal's leadership is one of the efforts to increase teacher performance. Among the principal's attempts to improve teacher performance are; First, the principal must have a strong leadership spirit, namely leadership that is able to influence all parties in order to achieve organizational goals. For this reason, leadership selection is an important factor in choosing credible leaders so that their abilities are recognized by all stakeholders. Leaders are not only able to divide jobs among teachers and education personnel but also know fundamental problems in education [12].

Principals need to optimize coaching for teachers through the implementation of academic supervision and more to fix the transformational leadership applied in schools during an attempt to increase teacher education effectiveness so that learning quality can be realized within the direction of achieving educational quality. For teachers to always improve the effectiveness of teaching in the classroom by establishing good cooperation with all components in schools, especially principals in implementing academic supervision and in implementing transformational leadership.

To improve the quality of national education, what must receive special attention is the implementation of classroom learning, because that is where the interaction of knowledge transfer to students occurs, to support this 
process requires the implementation of academic supervision that can touch directly to teachers, and support from transformational leadership. principals who can motivate and arouse teacher enthusiasm to find and implement reforms in the learning process in order to incorporate quality learning.

Second, the principal must be able to build cooperation with various parties. This collaboration is of course related to educators, employees / education staff, parents and the community. This means that the effort to achieve organizational/school goals is through other people. This means that leadership must be able to drive and direct the behavior of all related parties.

Third, in order to achieve the goals of education, teacher performance is an inseparable part of a system that begins with input, processes, and output an educational institution. Therefore, efforts to improve teacher performance in terms of professionalism as educators are absolutely necessary. In response to appreciating performance and professionalism, the government passed on Teachers and Lecturers which, among other things, regulates matters related to teacher professionalism [13].

Fourth, as a leader, the principal must be able to interpret and solve problems through various activities that can increase teacher active participation, such as actively participating in seminars and workshops related to the main task and function of teachers. This is in order to increase teacher participation in carrying out their duties, if leaders actively provide and motivate teachers to attend seminars and workshops on their main duties and functions, including leadership, of course it will have a positive impact on teacher performance.

From the research results, there are a number of factors that affect teacher performance, ranging from organizational culture, teacher competence, work motivation, principal leadership, and other factors. The principal's leadership is one of these factors that has a major impact on teacher performance. Good teacher performance will almost certainly be realized if the leadership - in this case, the principal - is aware of the factors that influence teacher performance

\section{CONCLUSION}

It is possible to draw the following conclusions based on the findings of the research: 1) the transformational leadership of the principal has a huge effect on the teacher success of SD Negeri 7 Muara Telang. The magnitude of the influence of transformational leadership is largely determined by the charismatic, inspirational, intellectual attitudes and sensitivity of the principal towards teachers and staff; 2) job motivation has a big impact on teacher success at SD Negeri 7 Muara Telang. The extent of the power of work motivation is due to stimulation to meet accomplishment needs, as well as the need for workplace security. as well as the need for manpower, and 3) the principal's transformational leadership and job encouragement have a major impact on the success of SD Negeri 7 Muara Telang since the principal's leadership attitude will further influence teacher performance by providing motivation in improving teacher performance.

\section{ACKNOWLEDGMENTS}

Our deepest gratitude goes to Teachers in Gugus Dua, Muara Telang District, Chancellor of Palembang PGRI University, Director of the Postgraduate Program of PGRI Palembang University and the Education Management Study Program of PGRI Palembang University, who have supported us in doing this extraordinary thing. This project is funded independently. We also want to thank our Education Management friends who helped us a lot in a short time frame to complete this project.

\section{REFERENCES}

[1] Dimyati, M. (2012). Belajar dan Pembelajaran [Learning and Learning]. Jakarta: Rineka Cipta.

[2] Sudarmanto. (2011). Kinerja dan Pengembangan Kompetensi SDM. Teori, Dimensi Pengukuran, dan Implementasi dalam Organisasi [HR Competency Performance and Development. Theory, Measurement Dimensions, and Implementation in Organizations]. Yogyakarta: Pustaka Pelajar.

[3] Wahjosumidjo. (2011). Kepemimpinan Kepala Sekolah [Principal Leadership]. Jakarta: Rajawali Press.

[4] Mulyasa, E. (2016). Menjadi kepala sekolah Profesional [Becoming the head of a professional school]. Bandung: PT. Remaja Rosdakarya.

[5] Haryono, M. (2014). Statistisk Penelitian [Research Statistics]. Bandung: Alfabeta.

[6] Djamarah. (2008). Psikologi Belajar [Psychology of Learning]. Jakarta: PT. Rineka Cipta

[7] Slameto. (2010). Belajar dan Faktor-Faktor Yang Mempengaruhi [Learning and Its Affecting Factors]. Jakarta: Rineka Cipta.

[8] Widiarochmawati, N. (2010). Kepemimpinan Kharismatik Wanita Kepala Sekolah Dasar di Kabupaten Tuban [Charismatic Leadership for Primary School Women Principals in Tuban Regency]. Jurnal Prospektus, Tahun VIII, Nomor 1, April 2010.

[9] Purwanto N. (2016). Administrasi dan Supervisi pendidikan [Administration and supervision of education]. Bandung: Remaja Rosdakarya. 
[10] Mukmin, H. (2014) Peranan Fakultas Dakwah Sebagai Lembaga Dakwah Kampus (LDK) dalam Pemberdayaan Masyarakat Islam di Wilayah Lampung [The Role of the Faculty of Da'wah as a Campus Da'wah Institution (LDK) in Empowering Islamic Communities in the Lampung Region]. Lampung: Pusat Penelitian dan Penerbitan Lembaga Penelitian dan Pengabdian Kepada Masyarakat, IAIN Raden Intan Lampung.

[11] Departemen Pendidikan Nasional. (2017). Kamus Besar Bahasa Indonesia [Indonesia Dictionary]. Jakarta: Balai Pustaka.

[12] Kartono, K. (2013). Pemimpin dan Kepemimpinan: Apakah Kepemimpinan Abnormal Itu? [Leaders and Leadership: What Is Abnormal Leadership?]. Jakarta: Raja Grafindo Persada.

[13] Undang-Undang RI No 14 tahun 2005 tentang guru dan dosen [Law No. 14 of 2005 on teachers and lecturers]. Bandung: Citra Utama. 